Revista Brasileira de

Engenharia Agrícola e Ambiental

v. 15, n.7, p.731-740, 2011

Campina Grande, PB, UAEA/UFCG - http://www.agriambi.com.br

agriambi

Protocolo 086.10 - 10/05/2010 • Aprovado em 08/04/2011

\title{
Mapeamento do potencial de erosão laminar na Bacia do Rio Japaratuba, SE, via SIG
}

\author{
Ricardo de Aragão ${ }^{1}$, José A. P. de Almeida ${ }^{2}$, \\ Eduardo E. de Figueiredo ${ }^{3} \&$ Vajapeyam S. Srinivasan ${ }^{3}$
}

RESU MO

A erosão do solo é a principal causa do empobrecimento precoce de terras produtivas e dentre as suas formas está a erosão laminar. Esta se caracteriza não apenas pela remoção de uma camada relativamente uniforme da superfície, mas também por seus nutrientes, sendo intensificada, portanto, pelas ações antrópicas. Para evitar ou reduzir seus impactos, fazem-se necessárias diretrizes para a adequação do uso e da ocupação às condições de cobertura vegetal, tipo de solo e topografia, através de mapas do potencial erosivo laminar da região de interesse, obtidos via sistemas de informações geográficas (SIG). N este trabalho foi desenvolvido o mapeamento do potencial erosivo laminar da bacia do rio Japaratuba, SE $\left(1685 \mathrm{~km}^{2}\right)$; trata-se de uma região sujeita a intensa atividade agrícola, pecuária e de mineração, onde só restam $6 \%$ da vegetação nativa. Os resultados mostram que $48,71 \%$ da área da bacia ficam nas classes de médio e alto potencial erosivo, indicando que a bacia está bastante impactada devido aos usos inadequados para as condições de solo e declividades.

Palavras-chave: potencial erosivo, impactos antrópicos, perda de solo

\section{Mapping the laminar erosion potential for the Japaratuba River Basin, SE via GIS}

\section{ABSTRACT}

Soil erosion is a natural phenomenon that reduces soil fertility and causes a great impact on agricultural areas. Laminar erosion is characterized by the removal of the top soil fairly uniformly as well as its nutrients, which is accelerated by human activities. To minimize the impacts it is necessary to adopt an adequate soil management that takes into account the type of the soil, relief, and vegetation cover. The soil management can be aided by mapping the erosive potential of a region using G IS tools. In this work, the technique that was used for mapping the erosive potential in the Japaratuba River Basin $\left(1685 \mathrm{~km}^{2}\right)$ located in the State of Sergipe is presented. The results show that $48.71 \%$ of the basin area lie within medium and high erosive potentials zones, suggesting the inadequate land use for the soil types and relief within the basin.

Key words: soil erosion, human impacts, soil loss

\footnotetext{
${ }^{1}$ DEC/UFS, Av. Marechal Rondon, s/n Jardim Rosa Elze, CEP 49100-000, São Cristóvão, SE. Fone: (79) 2105-6700. E-mail: ricardoaragao@ufs.br ${ }^{2}$ NUGEO/UFS, Av. Marechal Rondon, s/n. Fone: (79) 2105-6326. E-mail: jalmeida@ufs.br

3 U AEC/U FCG, Av. Aprígio Veloso 882, Bodocongó, CEP 58429-140, Campina Grande, PB. Fone: (83) 2101-1289; 2101-1156. E-mail: eneasef@yahoo.com, vajapeyam@yahoo.com
} 


\section{INTRODUÇÃO}

A erosão do solo é o processo de desagregação e deslocamento das partículas sólidas da superfície do solo ou do leito dos canais, devido a diversos agentes como o impacto das gotas de chuva e o escoamento (Bertoni \& Lombardi Neto, 2005; Albuquerque et al., 2005; Shih \& Yang, 2009). Ela se constitui na principal causa do empobrecimento precoce das terras produtivas, visto que as enxurradas, provenientes das águas que não foram retidas ou infiltradas no solo, transportam partículas de solo em suspensão e nutrientes necessários às plantas (Merritt et al., 2003; Decroix et al., 2008).

Dentre os tipos de erosão (laminar, em sulcos e voçorocas), a erosão laminar se destaca pela combinação da ação desagregadora do impacto das gotas de chuva (Petan et al., 2010; Santos et al., 2010) com a força de arrasto, causada pelo escoamento superficial (Decroix et al., 2008; Auerswald et al., 2009). O processo é contínuo, razão pela qual a erosão não pode ser evidenciada por simples inspeção visual, mas é possível ser detectada pela coloração das águas dos corpos hídricos e pelo estado da cobertura do solo (Inácio et al., 2007; Ribeiro \& Alves, 2008; Barbosa et al., 2009a). Os processos erosivos ocorrem naturalmente, de forma lenta e gradual, mas são intensificados em virtude das ações antrópicas, tais como desmatamentos, atividades agropecuárias e manejo inadequado do solo (Nunes et al., 2011). Nas áreas de clima tropical, como na região Nordeste, as chuvas ocorrem com grande intensidade e são concentradas em um curto período de tempo, o que agrava ainda mais o processo erosivo devido ao forte impacto das gotas de chuva (Martins et al., 2010; Santos et al., 2010).

Para mitigar os resultados dos processos erosivos, faz-se necessário um bom conhecimento da região de interesse e se adequar a ocupação às condições de cobertura vegetal, tipo de solo, topografia, sistema natural de drenagem e condições naturais de estabilidade dos taludes naturais ou artificiais. Neste sentido, uma das maneiras mais eficientes para fornecer subsídios à seleção de áreas prioritárias, do ponto de vista de conservação e recuperação do solo, é a utilização de mapas de potencial à erosão laminar, os quais poderão mostrar a expectativa de perda de solo sob sistemas de ocupação da terra e o zoneamento básico das áreas de restrição à ocupação (Pedro \& Lorandi, 2004; Guimarães \& Santos, 2007; Ribeiro \& Campos, 2007).

Dada à relevância do tema, diversos trabalhos têm sido desenvolvidos relacionando-se a integração de dados para a caracterização da degradação do solo, como ocorre no processo erosivo, com a aplicação de sistemas de informações geográficas, através do cruzamento de informações (Lorandi et al., 2001; Lufafaa et al., 2003; Guimarães \& Santos, 2007; Barbosa et al., 2009b). Neste sentido, nenhuma ação foi desenvolvida até o presente para a bacia do rio Japaratuba, ressaltando-se que há mais de dois séculos predominam nesta bacia, a criação de gado e a plantação de cana-de-açúcar para a produção de álcool e açúcar. Por causa dessas atividades restam, na bacia, apenas 6\% da cobertura nativa original (Aragão \& Almeida, 2009). A situação é preocupante visto que a região é uma das maiores produtoras de álcool combustível do Estado de Sergipe, que se sobressai como um dos grandes produtores da região Nordeste, condições em que as vastas áreas de solo arenoso da região, que ficam expostas durante o estágio inicial do desenvolvimento da cana-de-açúcar, estão sujeitas a uma grande erosão laminar.

Ante o exposto, este trabalho objetiva o mapeamento do potencial à erosão laminar na Bacia do Rio Japaratuba, SE, visando nortear o uso das suas terras e auxiliar na tomada de decisão quanto à identificação das áreas essenciais para a preservação do meio ambiente e das medidas de conservação.

\section{MATERIAL E MÉTODOS}

\section{A Bacia do Rio Japaratuba, SE}

A Bacia Hidrográfica do Rio Japaratuba, totalmente inserida no Estado de Sergipe (10 $10^{\circ}$ ' 00" e 10 47' 00" de latitude Sul e $36^{\circ} 48^{\prime} 00^{\prime \prime}$ e $37^{\circ} 19^{\prime} 00^{\prime \prime}$ de longitude oeste), possui uma área de $1685 \mathrm{~km}^{2}$, perímetro de $247,30 \mathrm{~km}$ e o rio principal tem extensão de $135 \mathrm{~km}$ (Figura 1). Dentre os afluentes que compõem a bacia, os mais importantes são: rio Siriri, pela margem direita, e o rio Japaratuba Mirim, pela margem esquerda (Aragão \& Almeida, 2009). Para esses rios, em termos de desenvolvimento da rede de drenagem, a bacia do rio Japaratuba, com sua drenagem principal, atinge a sexta ordem, a bacia do rio Siriri a quinta ordem e a Bacia do Rio Japaratuba-Mirim, a quinta ordem. Isto implica em que as referidas bacias são pouco drenadas. A bacia do rio Japaratuba abrange o território de vinte municípios sergipanos (Figura 1) dos quais apenas cinco estão nela totalmente inseridos (Capela, Carmópolis, Cumbe, General Maynard e Rosário do Catete), e os demais parcialmente inseridos. A população total na área da bacia é de

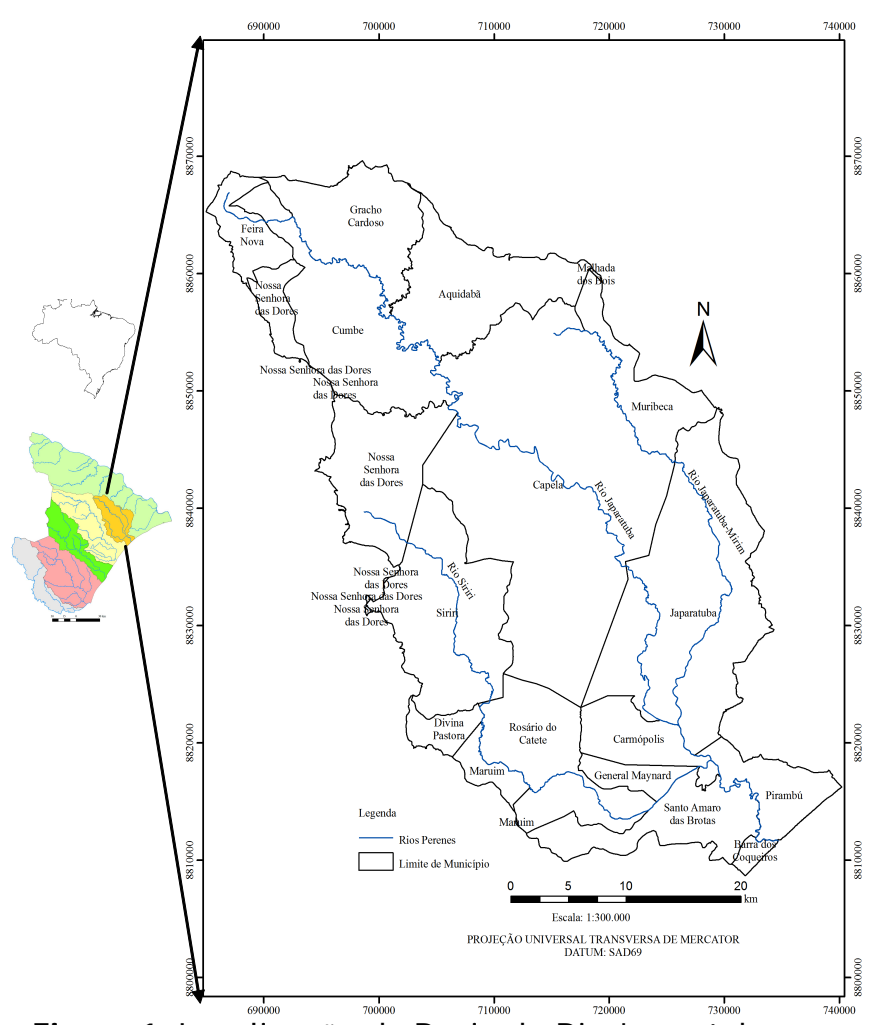

Figura 1. Localização da Bacia do Rio Japaratuba e os municípios que a compõem 
aproximadamente 400.000 habitantes, dentre eles $62,4 \%$ estão na área urbana e 37,6\% na área rural (Aragão \& Almeida, 2009).

O clima na bacia varia de subúmido, com excedentes hídricos no fim do outono e inverno (abril a agosto), a semiárido, com elevados valores de evapotranspiração potencial, pronunciada deficiência hídrica durante a primavera, o verão e o outono, e alta umidade somente nos meses de inverno. Da área total da bacia, $9,63 \%$ pertencem à região semiárida, 30,18\%, à porção litoral úmido e $60,17 \%$ estão localizados no agreste. A temperatura média anual na bacia é de $25^{\circ} \mathrm{C}$ e a umidade relativa do ar é da ordem de 74\% (SEPLANTEC, 2004).

O monitoramento hidrológico é feito através de cinco estações fluviométricas e o climatológico através de nove estações pluviométricas (convencional), duas estações pluviométricas automáticas (Aragão \& Almeida, 2009), uma estação climatológica convencional, operada pela Agência Nacional de Águas (ANA, 2002), e duas estações agrometeorológicas, instaladas nos municípios de Japaratuba (SRH-SE/CEMESE) e Rosário do Catete (Companhia Vale do Rio Doce) (Figuras 1 e 2). O período chuvoso na área da bacia ocorre entre abril e agosto (Figura 3), situando-se maio como o mês mais chuvoso; enfim, a precipitação média anual fica em torno de $1100 \mathrm{~mm}$.

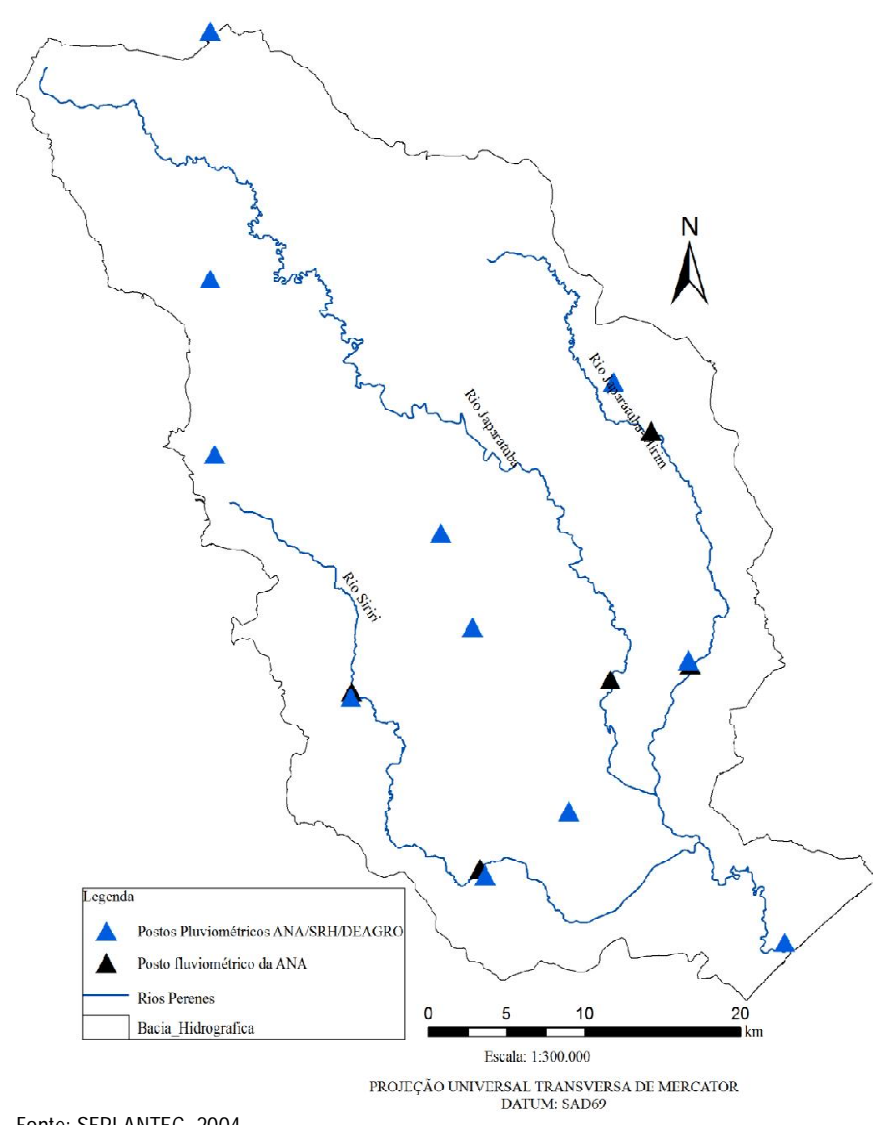

Figura 2. Localização dos postos pluviométricos e fluviométricos

Os tipos de solo (Figura 4) que compõem a bacia e seus respectivos percentuais com relação à área total são os seguintes (SEPLANTEC, 2004): vertissolos (3\% ou 50,83 $\left.\mathrm{km}^{2}\right)$; solos hidromórficos $\left(4 \%\right.$ ou $\left.68,19 \mathrm{~km}^{2}\right)$; solos arenoquartzosos

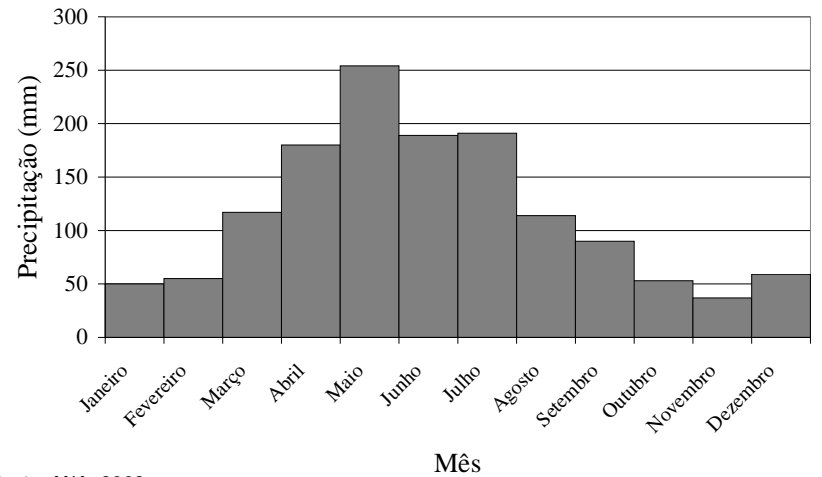

Fonte: ANA, 2002

Figura 3. Precipitação média mensal no médio Japaratuba (estação Fazenda Junco N ovo)

profundos $\left(3,5 \%\right.$ ou $\left.59,15 \mathrm{~km}^{2}\right)$; solos aluvionais $(4,21 \%$ ou $\left.70,89 \mathrm{~km}^{2}\right)$; solos podzólicos vermelho amarelo $(37,43 \%$ ou $\left.630,82 \mathrm{~km}^{2}\right)$; solos podzólicos vermelho amarelo eutrófico $\left(38,34 \%\right.$ ou $\left.648,10 \mathrm{~km}^{2}\right)$ e Latossolo vermelho amarelo $(7,27 \%$ ou $\left.122,10 \mathrm{~km}^{2}\right)$.

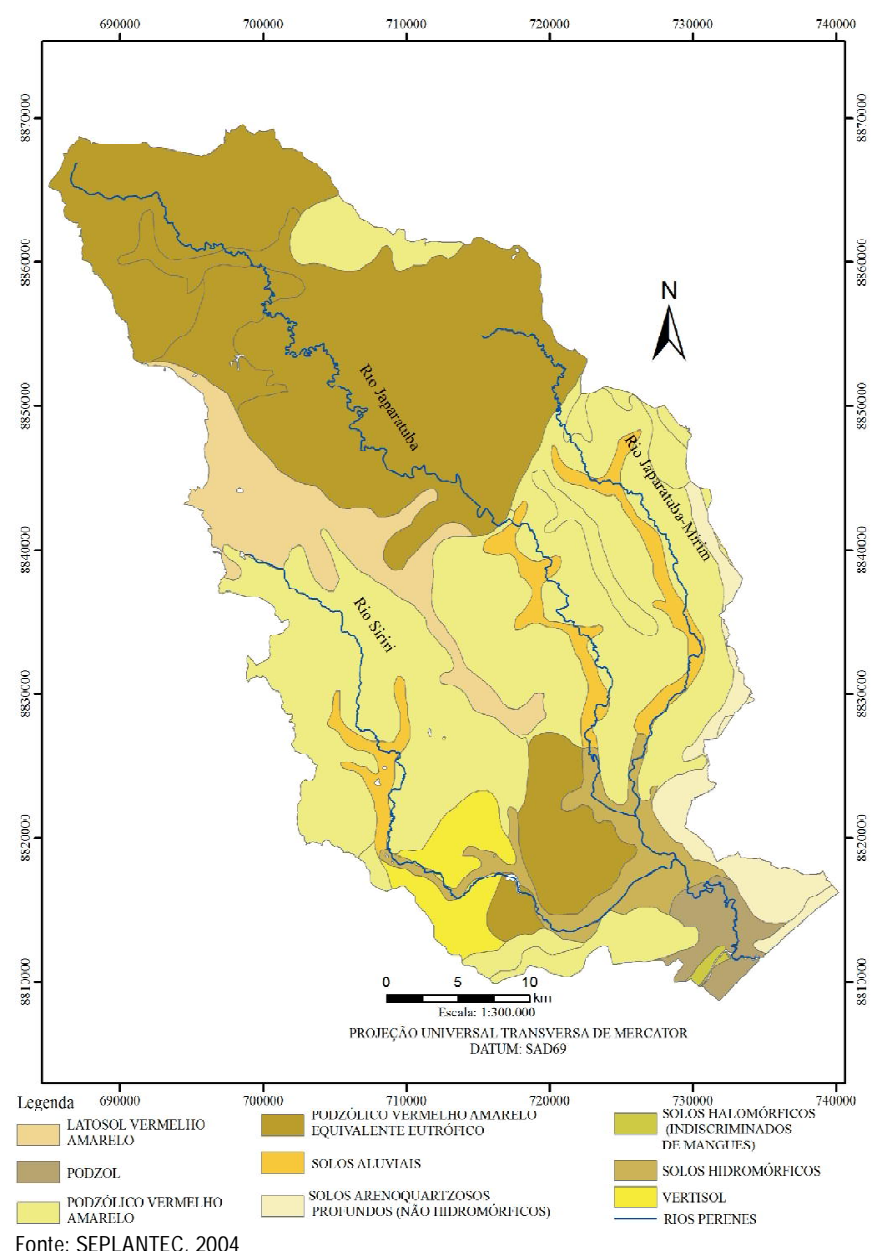

Figura 4. Mapa de solo da Bacia do Rio Japaratuba

Em se tratando de categorias de uso e ocupação de solo (Figura 5), se encontram os seguintes percentuais com relação à área total (SEPLANTEC, 2004): cidades $\left(0,46 \%\right.$ ou $\left.7,75 \mathrm{~km}^{2}\right)$, floresta $\left(6,74 \%\right.$ ou $\left.113,63 \mathrm{~km}^{2}\right)$, mangue $\left(0,57 \%\right.$ ou $\left.9,62 \mathrm{~km}^{2}\right)$, mata secundária $\left(18,40 \%\right.$ ou $\left.310,12 \mathrm{~km}^{2}\right)$, pastagem $<20 \%$, isto 
é, com predominância arbustiva arbórea com pasto $(0,36 \%$ ou $\left.6,07 \mathrm{~km}^{2}\right)$, pastagem $>20 \%$, i.e., com predominância de pasto $\left(49,63 \%\right.$ ou $\left.836,33 \mathrm{~km}^{2}\right)$, solos expostos $\left(0,38 \%\right.$ ou $\left.6,47 \mathrm{~km}^{2}\right)$, área cultivada $\left(22,22 \%\right.$ ou $\left.374,41 \mathrm{~km}^{2}\right)$ e área embrejada $(1,23 \%$ ou $20,81 \mathrm{~km}^{2}$ ); além desses usos se ressalta, também, a exploração mineral (petróleo - Carmópolis, Japaratuba, Siriri, Rosário do Catete; Potássio - Rosário do Catete).

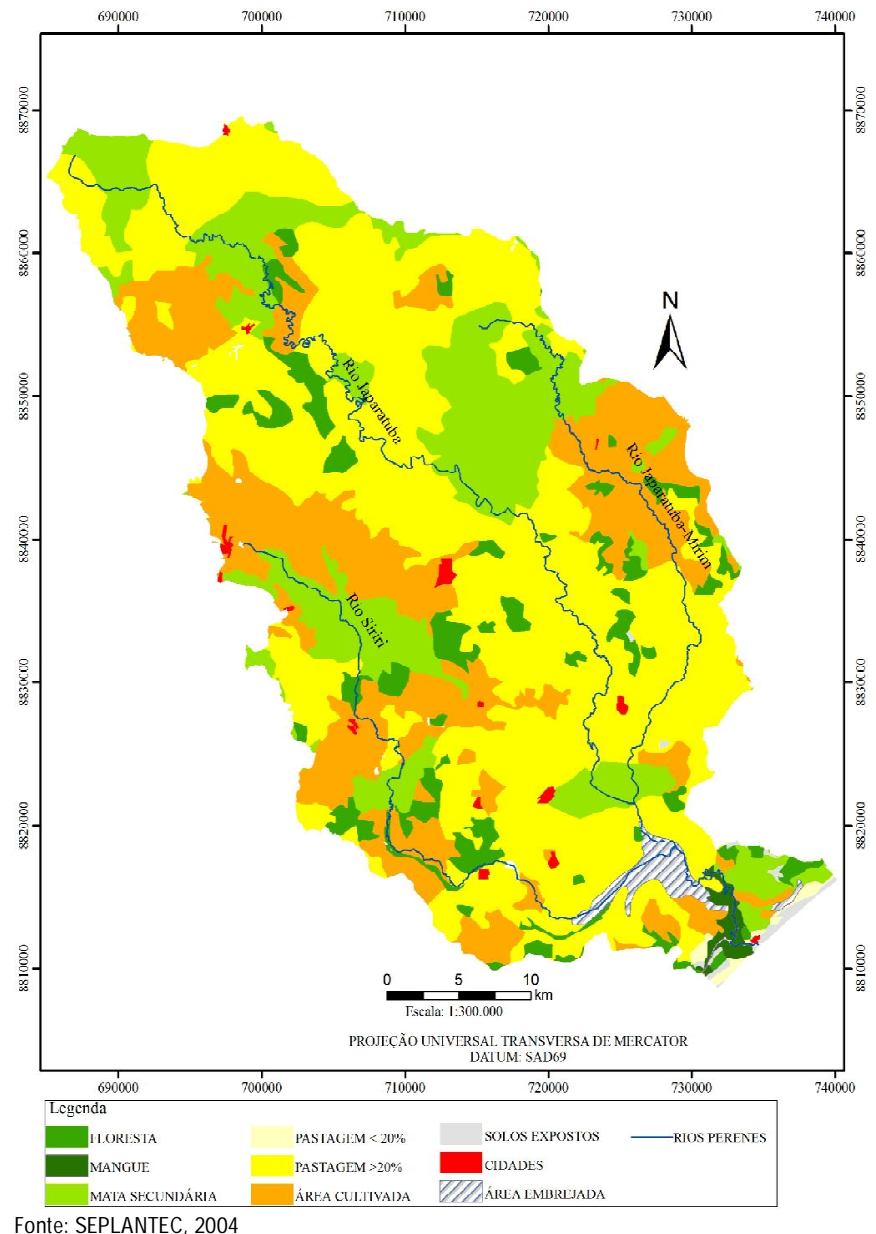

Figura 5. U so do solo na Bacia do Rio Japaratuba

\section{Metodologia e dados utilizados na sua aplicação}

O desenvolvimento do mapa de potencial à erosão laminar segue a metodologia descrita por Salomão (1999), que se baseia no cruzamento matricial do mapa de suscetibilidade à erosão laminar com o mapa de uso e ocupação atual do solo. O mapa de suscetibilidade à erosão laminar reflete as características naturais do terreno em face do desenvolvimento dos processos erosivos e sua determinação toma por base os fatores naturais, principais influentes nesses processos, a saber: erosividade da chuva, erodibilidade do solo e a declividade das encostas. Cada um desses fatores resultará em determinado índice ou classe, que reflete o grau de susceptibilidade no processo erosivo.

Uma vez que os dados relativos aos fatores citados sejam obtidos, o cruzamento matricial entre a erodibilidade do solo e sua declividade é realizado, resultando no mapa preliminar de suscetibilidade à erosão; em seguida, os dados deste mapa preliminar são cruzados com os dados relativos ao índice de erosividade da chuva, resultando no mapa de suscetibilidade à erosão laminar, cujo resultado indica as seguintes classes: a) extremamente suscetível; b) moderadamente suscetível; c) pouco suscetível e d) pouco a não suscetível; prosseguindo, as informações sobre os usos e as ocupações do solo são classificadas em cinco grandes classes: I) cobertura vegetal de baixo e médio porte, com intensa atividade antrópica; II) cobertura vegetal de baixo e médio porte, com atividade antrópica moderada; III) cobertura vegetal de baixo a médio porte, com atividade antrópica muito reduzida; IV) cobertura vegetal de porte alto a médio, com atividade antrópica muito reduzida e V) espelho d'água e várzeas.

A combinação de todas as informações acima dá lugar ao mapa atual de potencial à erosão laminar, apresentado em três classes (Bertoni \& Lombardi Neto, 2005): 1) alto potencial; 2) médio potencial e 3) baixo potencial, com base na compatibilidade do uso atual do solo com a suscetibilidade à erosão laminar da região na qual este solo está localizado.

\section{Dados utilizados no emprego da metodologia}

A obtenção dos dados pedológicos e de uso do solo é feita através de levantamentos cartográficos e imagens sobre a ocupação e uso do solo, os quais foram anteriormente descritos. A erosividade da chuva (potencial da chuva de causar erosão em uma área sem proteção ou sem cobertura vegetal) depende da sua energia cinética e da intensidade (Gonçalves et al., 2006; Bazzano et al., 2010). Para sua determinação são necessários dados pluviográficos, que não são disponíveis com frequência. No presente caso empregou-se para contornar o problema da falta de dados pluviográficos a metodologia descrita por Bertoni \& Lombardi Neto (2005), que fornece o índice de erosividade média mensal (EI) para um posto pluviométrico a partir de seus dados de precipitação mensal e anual conforme aEq.1:

$$
\mathrm{EI}=67,355\left(\mathrm{r}^{2} / \mathrm{P}\right)^{0,85}
$$

donde:

$$
\begin{aligned}
& \mathrm{EI} \text { - índice de erosividade média mensal, } \mathrm{MJ} \mathrm{mm} \mathrm{ha}^{-1} \mathrm{mês}^{-1} \\
& \mathrm{r}
\end{aligned}
$$

O valor de EI para toda a bacia foi calculado através dos dados pluviométricos dos postos localizados no seu interior (nove postos) e nas proximidades de sua fronteira (nove postos); posteriormente, os resultados foram interpolados através do emprego do programa SPRING (Câmara et al., 1996) para toda a bacia.

A erodibilidade do solo (susceptibilidade do solo para erosão, principalmente pela erosão hídrica), que depende do tipo do solo e do seu manejo, foi determinada conforme Crepani et al. (2008), que associaram diversos tipos de solo brasileiro a um valor de erodibilidade, de acordo com cada tipo de solo, em uma escala que vai de 1 (menor erodibilidade) a 3 (maior erodibilidade). Referida metodologia foi adotada neste estudo haja vista que engloba os solos que compõem a Bacia do Rio Japaratuba. 
Tabela 1. Classes de declividade para a Bacia do Rio Japaratuba

\begin{tabular}{|c|c|}
\hline$\%$ & Relevo modelado \\
\hline $0-2 \%$ & $\begin{array}{l}\text { Plano - Áreas planas ou quase planas, nas quais o } \\
\text { escoamento superficial é lento ou muito lento. Esta } \\
\text { classe não oferece dificuldade ao uso de máquinas } \\
\text { agrícolas. }\end{array}$ \\
\hline $2-5 \%$ & $\begin{array}{l}\text { Suave ondulado - Os terrenos desta classe têm declives } \\
\text { suaves e aqui geralmente o deflúvio é lento ou médio. } \\
\text { Nesta classe o trabalho mecanizado usual é de fácil } \\
\text { operação. }\end{array}$ \\
\hline $5-10 \%$ & $\begin{array}{l}\text { Ondulado - Engloba terrenos inclinados em relevo } \\
\text { geralmente ondulado. } 0 \text { deflúvio é médio ou rápido. } \\
\text { Comumente, o declive não prejudica o uso de máquinas } \\
\text { agrícolas. Em alguns casos, a erosão hídrica pode ser } \\
\text { controlada com práticas simples. }\end{array}$ \\
\hline $10-25 \%$ & $\begin{array}{l}\text { Forte ondulado - Compreende terrenos inclinados em } \\
\text { relevo ondulado. Geralmente, o escoamento superficial é } \\
\text { rápido para a grande maioria dos solos. } 0 \text { uso de } \\
\text { máquinas agrícolas é parcialmente prejudicado. A erosão } \\
\text { hídrica compromete o cultivo intenso. }\end{array}$ \\
\hline $25-45 \%$ & $\begin{array}{l}\text { Montanhoso - Constitui terrenos muito inclinados a } \\
\text { fortemente inclinados e o escoamento superficial é muito } \\
\text { rápido. Nesta classe a grande maioria dos solos é } \\
\text { extremamente suscetível à erosão e os terrenos devem } \\
\text { ser utilizados apenas para cultivos perenes, pastagens ou } \\
\text { reflorestamentos. }\end{array}$ \\
\hline$>45 \%$ & $\begin{array}{l}\text { Escarpado - Há sérios impedimentos ao uso, exigindo } \\
\text { práticas muito complexas (projetos de drenagem), e } \\
\text { devem ser mantidos, preferencialmente, como áreas de } \\
\text { preservação ambiental. }\end{array}$ \\
\hline
\end{tabular}

Obtém-se a declividade das encostas através do emprego do software SPRING (Câmara et al., 1996) aos dados de elevação da bacia do rio Japaratuba (Rabus et al., 2003), oriundos do programa Shuttle Radar Topography Mission (SRTM), considerando-se seis intervalos de declividade (Tabela 1), que englobam os relevos e solos da área de estudo.

\section{Mapa de suscetibilidade à erosão laminar}

$\mathrm{O}$ cruzamento matricial das informações relativas à erodibilidade do solo, à erosividade da chuva e às classes de declividade, resultou em cinco classes ( $\mathrm{I}$ a $\mathrm{V}$ ) de suscetibilidade a erosão laminar para a Bacia do Rio Japaratuba (Tabela 2), as quais estão relacionadas à capacidade de uso da terra (Bertoni \& Lombardi Neto, 2005).

Na classe I estão os solos extremamente suscetíveis, terrenos que apresentam problemas complexos de conservação; são áridos, muito acidentados e escarpados, declive superior a $20 \%$, indicados para preservação ou para reflorestamento.

Os solos da classe II são muito suscetíveis e os terrenos apresentam declividade de 12 a $20 \%$; são parcialmente favoráveis à ocupação por pastagens e indicados para reflorestamento. Na classe III estão os solos moderadamente suscetíveis, alta a baixa fertilidade, declive de 12 a $20 \%$, indicados para pastagens e culturas perenes. A classe IV consiste de solos pouco suscetíveis, declividade variando de 6 a $12 \%$, indicados para pastagens e culturas perenes e, eventualmente, para culturas anuais, porém exigindo práticas intensivas mecanizadas de controle da erosão. Na classe V estão os solos pouco suscetíveis com terrenos sem problemas de conservação mas exigindo técnicas especiais de cultivo por se constituírem de solos encharcados.

O resultado do cruzamento matricial mostrado na Tabela 2 foi espacializado através do programa SPRING (Câmara et al., 1996), permitindo a elaboração do mapa de suscetibilidade à erosão laminar, que reflete as características naturais do terreno em face do desenvolvimento dos processos erosivos (Salomão, 1999).

\section{Mapa de potencial à erosão laminar}

Para determinar o mapa de potencial à erosão laminar da bacia do rio Japaratuba, levou-se em consideração o mapa de suscetibilidade à erosão e o mapa de uso e ocupação do solo. Este processo considerou as diversas ações antrópicas no processo erosivo e as áreas de igual suscetibilidade à erosão, mas ocupadas de maneiras diferentes. Neste intento, as nove classes de uso e ocupação do solo da bacia do rio Japaratuba (Figura 5) foram reclassificadas em cinco grandes classes de uso e ocupação do solo, com base no estado da cobertura do solo (Salomão, 1999), sendo: Classe I: cobertura vegetal de baixo e médio porte, com intensa atividade antrópica (culturas anuais, estradas e áreas urbanizadas) - engloba as classes Cidades e Solos Expostos. Classe II: cobertura vegetal de baixo e médio porte, com atividade antrópica moderada (culturas perenes, cana-de-açúcar e pastagens) - engloba as classes Pastagem $>20 \%$ e Área Cultivada. Classe III - cobertura vegetal de baixo a médio porte, com atividade antrópica muito reduzida (pasto sujo e campo cerrado) - esta classe engloba a classe Pastagem $<20 \%$. Classe IV - cobertura vegetal de porte alto a médio, com atividade antrópica muito reduzida (reflorestamento, capoeirão e floresta) - esta classe engloba as classes Floresta

Tabela 2. Classes de suscetibilidade à erosão laminar

\begin{tabular}{|c|c|c|c|c|c|c|c|c|}
\hline \multirow{2}{*}{ Erodibilidade } & \multirow{2}{*}{ Resistência à erosão } & \multirow{2}{*}{ Classe de solo } & \multicolumn{6}{|c|}{ Declividade $(\%)^{*}$} \\
\hline & & & $0-2$ & $2-5$ & $5-10$ & $10-25$ & $25-45$ & $>45$ \\
\hline 2 & Baixa & Podzólico Vermelho Amarelo Equivalente Eutrófico & IV & III & $\|$ & । & । & I \\
\hline 2 & Baixa & Podzólico Vermelho Amarelo & IV & IV & ॥ & I & I & 1 \\
\hline 1 & Moderada & Latossolo Vermelho Amarelo & V & V & IV & IV & III & $\|$ \\
\hline 3 & Muito baixa & Solos Aluviais & $\|$ & $\|$ & $\|$ & 1 & l & 1 \\
\hline 3 & Muito baixa & Solos Arenoquartizosos & $\|$ & $\|$ & II & i & I & i \\
\hline 3 & Muito baixa & Solos Hidromórficos & $\|$ & $\|$ & $\|$ & i & i & i \\
\hline 3 & Muito baixa & Vertis solo & $\|$ & $\|$ & II & I & I & i \\
\hline 2 & Baixa & Podzol & IV & IV & $\|$ & i & i & i \\
\hline 3 & Muito baixa & Solos Halomórficos & IV & IV & $\|$ & । & I & i \\
\hline
\end{tabular}


e Mata Secundária. Classe V - espelho d'água e várzeas, cujo potencial erosivo pode ser considerado nulo - esta classe engloba as classes Mangues e Áreas Embrejadas.

Os resultados da reclassificação de uso do solo, juntamente com o mapa de suscetibilidade, foram cruzados, resultando nas classes de potencial à erosão da Tabela 3, as quais são qualificadas em seguida.

Tabela 3. Classes de potencial à erosão laminar

\begin{tabular}{cccccc}
\hline Classe de suscetibilidade a & \multicolumn{5}{c}{ Classe de ocupação atual das terras } \\
\cline { 2 - 6 } erosão laminar & I & II & III & IV & V \\
I & I & I & I & II & - \\
II & I & II & II & III & - \\
III & II & II & II & III & - \\
IV & II & III & III & III & - \\
V & III & III & III & III & III \\
\hline
\end{tabular}

Fonte: Adaptado de Salomão (1999)

* I - Classe l: cobertura vegetal de baixo e médio porte, com intensa atividade antrópica;

II - Classe II: cobertura vegetal de baixo e médio porte, com atividade antrópica moderada;

III - Classe III: cobertura vegetal de baixo a médio porte, com atividade antrópica muito reduzida;

IV - Classe IV: cobertura vegetal de porte alto a médio, com atividade antrópica muito reduzida;

V - Classe V: espelho d'água e várzeas, cujo potencial erosivo pode ser considerado nulo

** I - Classe I: alto potencial; II - Classe II: médio potencial; III - Classe III: baixo potencial

Classe I - Alto potencial - o uso atual do solo é incompatível com a suscetibilidade à erosão laminar. Classe II- médio potencial - uso atual do solo é incompatível com a suscetibilidade à erosão laminar porém possível de ser controlada com práticas conservacionistas adequadas. Classe III - baixo potencial - uso atual do solo é compatível com a suscetibilidade à erosão laminar. As classes de potencial à erosão laminar presentes na Tabela 3, foram espacializadas através do programa SPRING (Câmara et al., 1996), resultando no mapa de potencial à erosão laminar.

\section{Resultados E DisCUSSÃo}

\section{Tipo, uso e cobertura do solo}

Os dados da bacia sobre os tipos de solo (Figura 4), mostram que o grande percentual da área da bacia $(75,77 \%)$ é coberto de solos podzólico vermelho amarelo que, segundo Crepani et al. (2008), são solos pouco desenvolvidos, pouco profundos, menos estáveis e variam de medianamente a muito vulneráveis aos processos erosivos (Tabela 2).

Nota-se que, em termos de uso e ocupação da terra (Figura 5), um grande percentual (50\% ou $\left.842,40 \mathrm{~km}^{2}\right)$ está relacionado à pastagem ou à área cultivada, principalmente com cana-de-açúcar, cultivo este muito tradicional na região. A área remanescente de floresta nativa é próxima a $6 \%$ do valor inicial e tende a diminuir com o avanço da área plantada de cana-de-açúcar ou do aumento da criação do gado (Aragão \& Almeida, 2009). Visando avaliar como se deu o uso do solo na área da bacia em diferentes épocas, Aragão \& Almeida (2009) utilizaram imagens dos satélites LANDSAT 5 e 7, sensores $\mathrm{TM}$ e $\mathrm{TM}^{+}$, obtidas para três diferentes datas (09/09/1997; 12/09/2001; 07/12/2006) respectivamente, e verificaram uma variação substancial nas áreas de pastagens e de cultivo (Figuras 6 e 7). Esta variação ocorreu de acordo com as necessidades econômicas de uma produção maior ou menor de álcool combustível, de açúcar ou de gado de corte. Essas mudanças, juntamente com as condições topográficas, pedológicas e pluviométricas da bacia, são determinantes para o avanço do processo de erosão laminar. $\mathrm{O}$ fator agravante neste manejo de solo é que, ora são desmatadas grandes áreas para plantar, ora elas são conservadas para pasto, porém pisoteadas pelo gado, o que reduz a infiltração e aumenta o processo de escoamento superficial, incrementando a erosão e o transporte de sedimento para os corpos hídricos. Nesta visão, foi nas cidades de Capela, Japaratuba, Carmópolis, General Maynar, Sirir e Cumbe, que ocorreu o maior crescimento de área cultivada no período analisado (Figura 7).

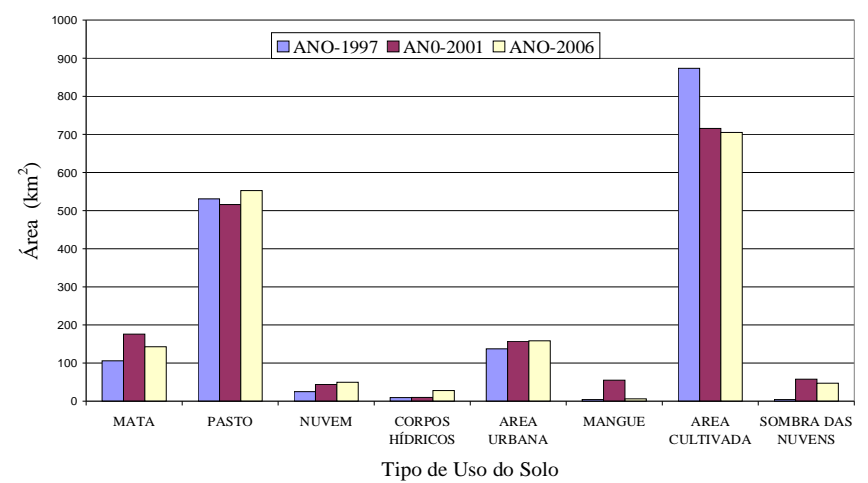

Fonte: Aragão \& Almeida (2009)

Figura 6. U so do solo, de acordo com a classificação das imagens de diferentes datas

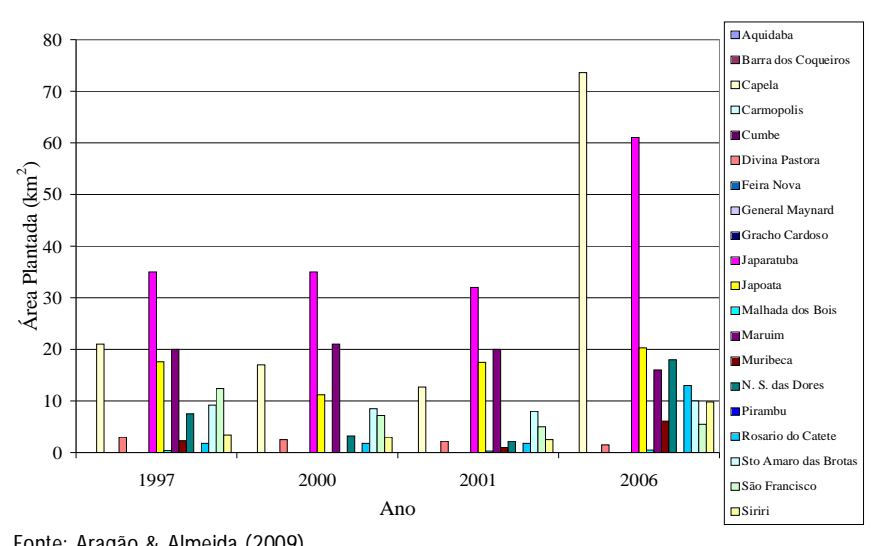

Figura 7. Área plantada de cana-de-açúcar por município na bacia do rio Japaratuba

\section{Erosividade da chuva}

A aplicação da metodologia descrita por Bertoni \& Lombardi Neto (2005), para a obtenção de erosividade da chuva, levou à determinação dos valores de erosividade média mensal e anual nas estações pluviométricas internas (Figura 2) e periféricas à bacia. Para os dados analisados, ela forneceu o valor médio anual de erosividade de 5638,3 $\mathrm{MJ} \mathrm{mm} \mathrm{ha}^{-1}$ ano $^{-1}$ com o coeficiente de variação de $30 \%$.

A erosividade anual mais elevada foi na estação Divina Pastora (7897,7 MJ mm ha ${ }^{-1}$ ano $^{-1}$ ), que fica na fronteira sudoeste da bacia, e a erosividade mais baixa, 2144,8 $\mathrm{MJ} \mathrm{mm} \mathrm{ha}^{-1} \mathrm{ano}^{-1}$, foi na estação Muribeca, na parte nordeste da bacia, na região climática de transição entre o agreste e o semiárido.

O mês que apresentou o maior valor de erosividade média foi maio (1260,5 MJ mm ha-1 mês $\left.^{-1}\right)$ e o mês de dezembro indicou a menor erosividade média $\left(67,3 \mathrm{MJ} \mathrm{mm} \mathrm{ha}^{-1} \mathrm{mês}^{-1}\right)$. Seguindo a tendência da chuva, o quadrimestre mais erosivo vai de abril 
até julho, justamente no período de colheita da cana-de-açúcar quando a terra, bastante movimentada, tende a se soltar e ficar fácil de ser erodida.

Visando analisar o processo erosivo devido à chuva no restante da bacia e considerando ser maio o mês mais chuvoso e dezembro o mês mais seco, os dados de erosividade média mensal foram espacializados para toda a bacia, através do software SPRING (Câmara et al., 1996), resultando nas Figuras 8 e 9 . Observa-se que, para o mês de maio, o processo erosivo tende a ser mais intenso do litoral para o interior, no sentido sudeste-sudoeste; para o mês de dezembro o crescimento é de sudoeste para nordeste. Também é possível verificar que os municípios mais afetados pelas chuvas intensas são Carmópolis, Capela e Japaratuba, Siriri e Rosário do Catete (Figura 1), justamente aqueles em que os processos antrópicos (agropecuária) e de exploração mineral (petróleo-Carmópolis; potássio-Rosário) são mais intensos (Figuras 6 e 7).

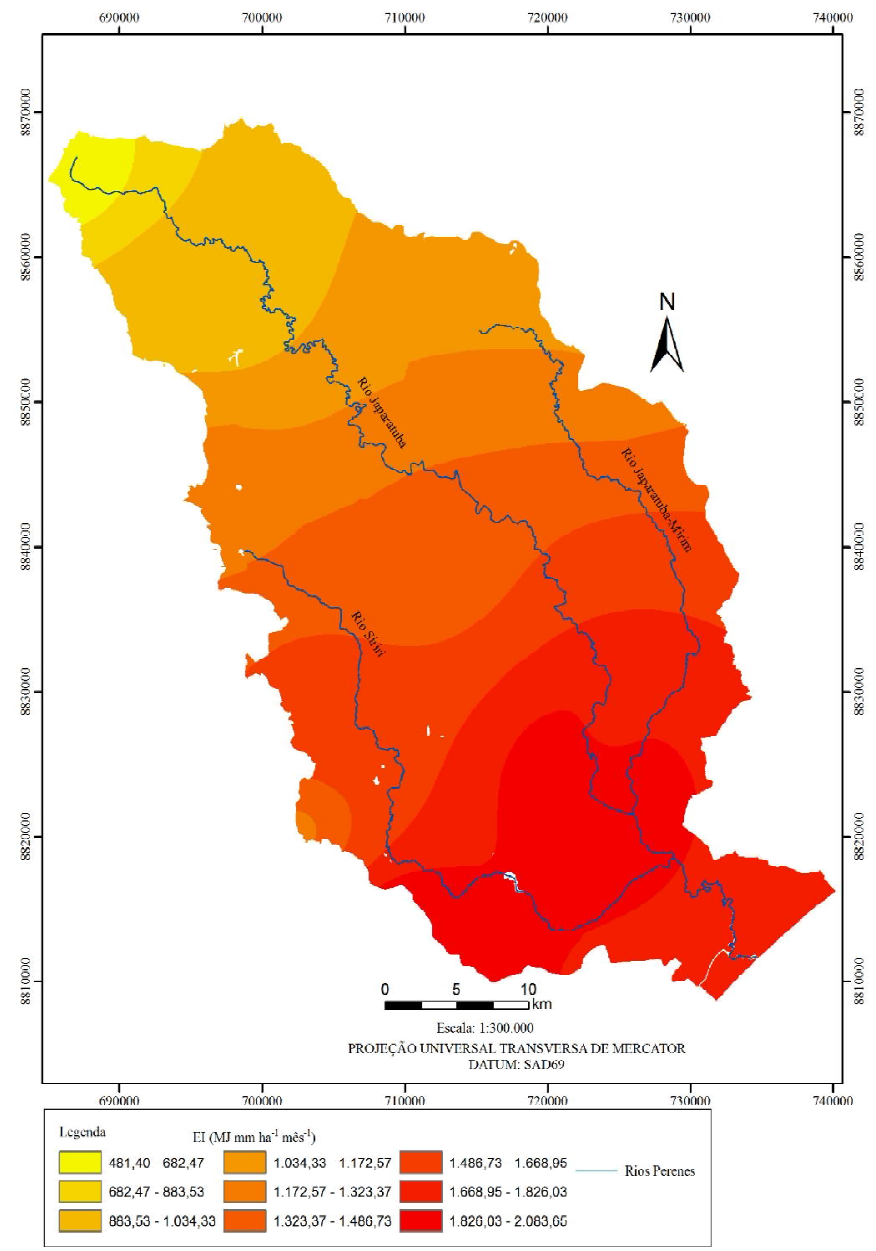

Figura 8. Erosividade média para o mês de maio

\section{Declividade e relevo}

A distribuição do relevo da bacia em categorias resultou no mapa de declividades mostrado na Figura 10. Em relação à área da bacia, conclui-se que $32,11 \%$ estão na faixa de declividade de $5-10 \%$ (relevo ondulado), 26,80\% se situam na faixa de $2-5 \%$ (relevo suave), $22,01 \%$ se acham na faixa de $10-25 \%$ (forte ondulado). Nota-se que grandes áreas estão em classe de declividade propícia à erosão. Na faixa de relevo ondulado (5-

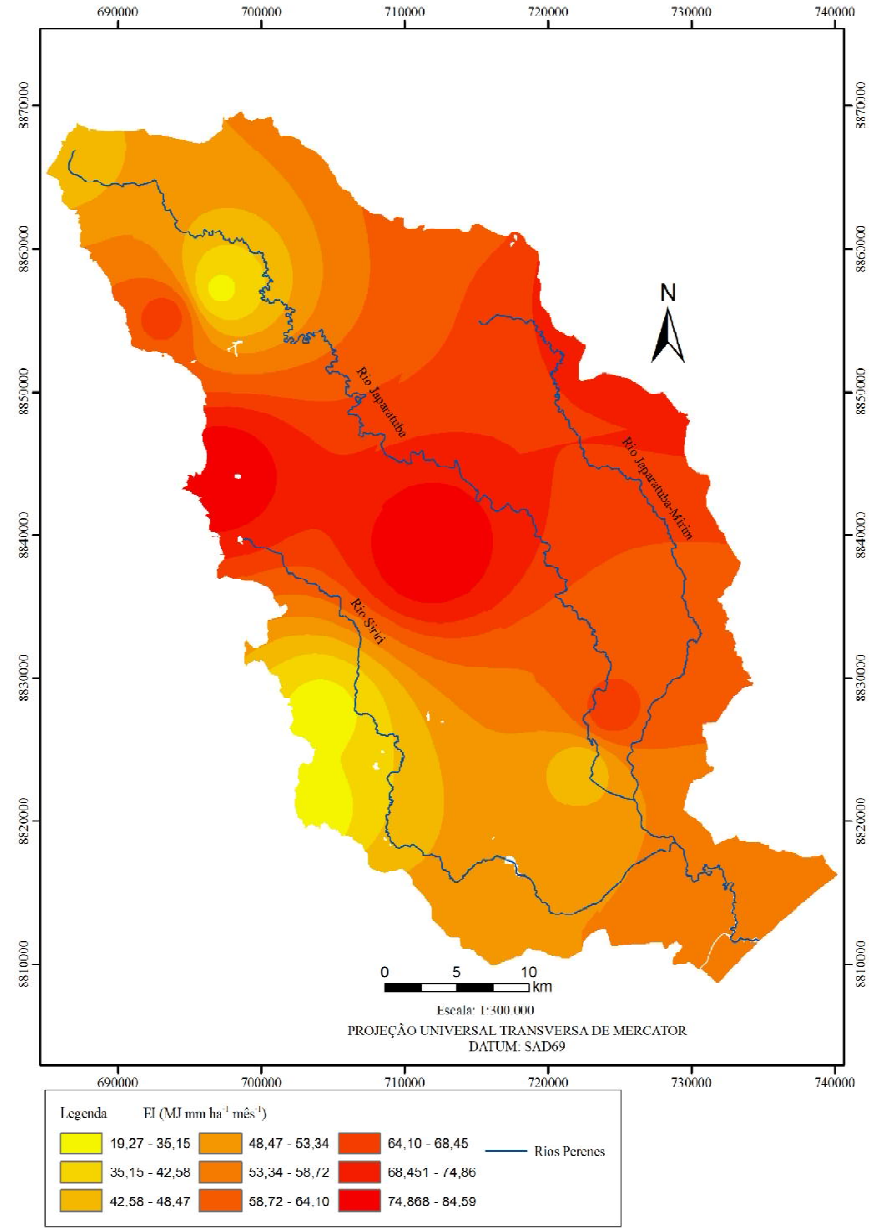

Figura 9. Erosividade média para o mês de dezembro

10\%), a erosão hídrica pode ser controlada com práticas simples, porém normalmente são necessárias práticas complexas de conservação do solo, como terraceamento, plantio direto etc., para que seja cultivado intensamente (Bertoni \& Lombardi Neto, 2005).

Através das diversas visitas às várias localidades na área da bacia, constatou-se que a região cuja declividade está entre 10 e 25\%, concentra usinas de álcool e açúcar (Figuras 1, 5, 7, 10). Por outro lado, a criação de gado se concentra na faixa de declividade de $2-10 \%$ (Figura 10). O mapa também mostra um grande planalto (declividade de $0-2 \%$ ), na região do rio Siriri (Figuras 1,2) onde há também a plantação de cana-de-açúcar.

\section{Mapa de suscetibilidade à erosão laminar}

O mapa de suscetibilidade à erosão laminar (Figura 11) e os dados relacionados mostram que aproximadamente $60 \%$ da área da bacia estão entre a classe I, extremamente suscetível $(21,22 \%)$ e a classe II, muito suscetível $(38,65 \%)$, cobrindo as cidades de Capela, Siriri, Carmópolis, Rosário do Catete e Japaratuba. Os solos das regiões citadas são predominantemente podzólico vermelho amarelo, reconhecidamente de média a alta erodibilidade (Tabela 2), Crepani et al. (2008). Aárea extremamente suscetível se encontra na classe de declividade $>10 \%$, encontrada nos vales dos rios principais e a área muito suscetível se encontra na classe entre 5 e $10 \%$. 


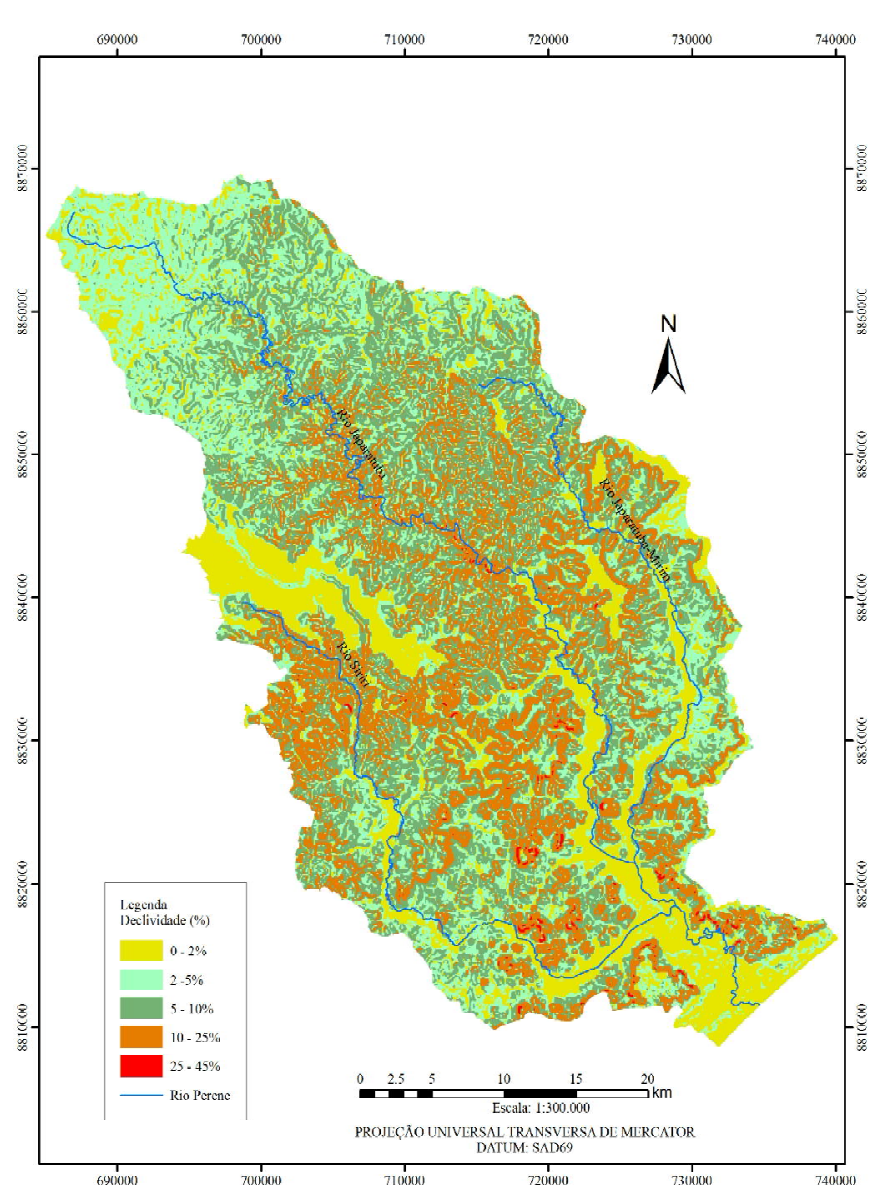

Figura 10. Mapa de declividade da Bacia do Rio Japaratuba

Apenas $13,35 \%$ da área total são classificados moderadamente suscetível (classe III, Tabela 2), compreendendo Feira Nova, Gracho Cardoso, Cumbe e Aquidabã, e cobrem dois tipos de solo: podzólico vermelho-amarelo equivalente eutrófico (cuja classe de declividade está entre 2 e $5 \%$ ) e Latossolo vermelho-amarelo, situado na classe de declividade entre 25 e $45 \%$ (nível 1 de erodibilidade).

Os solos do tipo podzol, halomórficos e uma porção dos podzólicos vermelho-amarelo (Figura 5), estão localizados na classe pouco suscetível $(22,38 \%)$, classe IV, e classe de declividade entre 0 e $5 \%$ e pouco contribuem para o processo erosivo (Salomão, 1999), Figuras 10 e 11. A classe pouco a não suscetível (4,37\%), classe V, se resume ao Latossolo vermelhoamarelo que se encontra na faixa de declividade de 0 a $5 \%$, bastante resistente ao processo erosivo (Tabela 2).

Com relação ao Latossolo vermelho-amarelo, que cobre $7,27 \%$ da área da bacia $\left(122,10 \mathrm{~km}^{2}\right)$, é interessante ressaltar que, dependendo da declividade do local, a porção deste tipo de solo poderá ser classificada numa larga faixa, desde muito suscetível ao processo erosivo a pouco a não suscetível à erosão (Tabela 2). O mapa de suscetibilidade à erosão laminar mostra as áreas dos municípios de Capela, Siriri, General Maynard, Camópolis e Japaratuba como sendo as extremamente suscetíveis à erosão laminar e, de forma geral, todos os municípios se encontram parcial ou completamente inseridos na classe muito suscetível à erosão laminar.

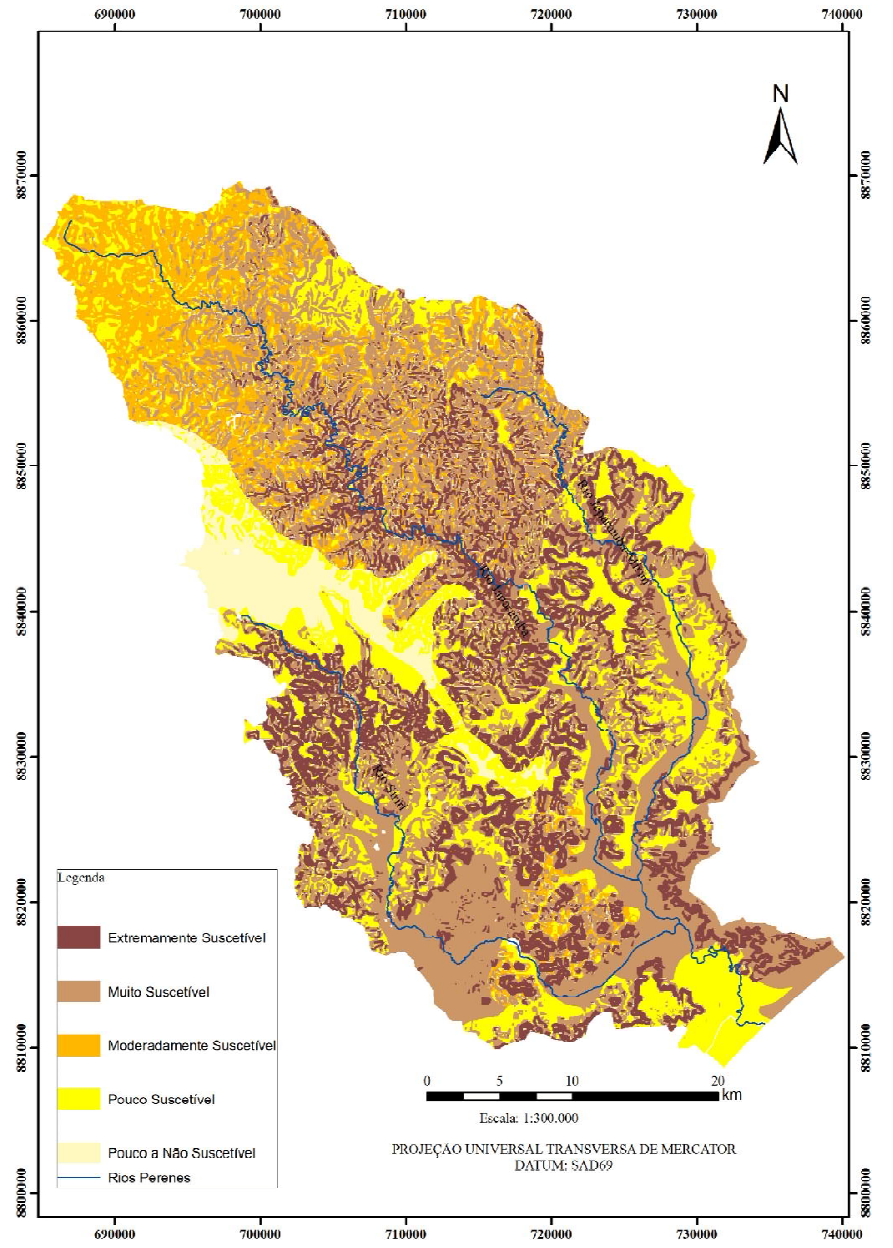

Figura 11. M apa de suscetibilidade a erosão laminar

\section{Mapa de potencial à erosão laminar}

A espacialização dos dados sobre potencial a erosão laminar (Tabela 3) resultou no mapa de potencial à erosão laminar (Figura 12), observando-se que $48,71 \%$ da área da bacia incluem a classe II, de médio potencial à erosão laminar $(34.06 \%$ ou 573,83 $\mathrm{km}^{2}$ ), e a classe I de alto potencial $\left(14.65 \%\right.$ ou $\left.246,88 \mathrm{~km}^{2}\right)$, compreendendo os municípios de Capela, Siriri, Carmópolis, Japaratuba. De acordo com Salomão (1999), o uso atual do solo nessas áreas é incompatível com a suscetibilidade à erosão laminar porém esta é possível de ser controlada com práticas conservacionistas apropriadas. Tais características podem levar ao desen volvimento de voçorocas de encostas, ravinas, sulcos frequentes e erosão laminar intensa. A carga de sedimento resultante desses processos poderá alcançar os corpos de água provocando seu assoreamento.

Como agravante, as áreas citadas estão localizadas na classe de declividade entre 10 e $25 \%$ e apresentam as condições de moderadamente suscetível (classe III) até extremamente suscetível (classe I). Neste sentido, diversas ações de mobilização para conservação do solo precisam ser efetuadas para evitar que as condições do solo sejam exauridas a ponto de não se tornaram improdutivas.

Considerando-se as informações ilustradas nas Figuras 5 e 12 , nota-se que as áreas relativas a médio e alto potencial à erosão laminar são aquelas nas quais ocorrem a pastagem e o cultivo de cana-de-açúcar. Na classe relativa ao médio potencial 


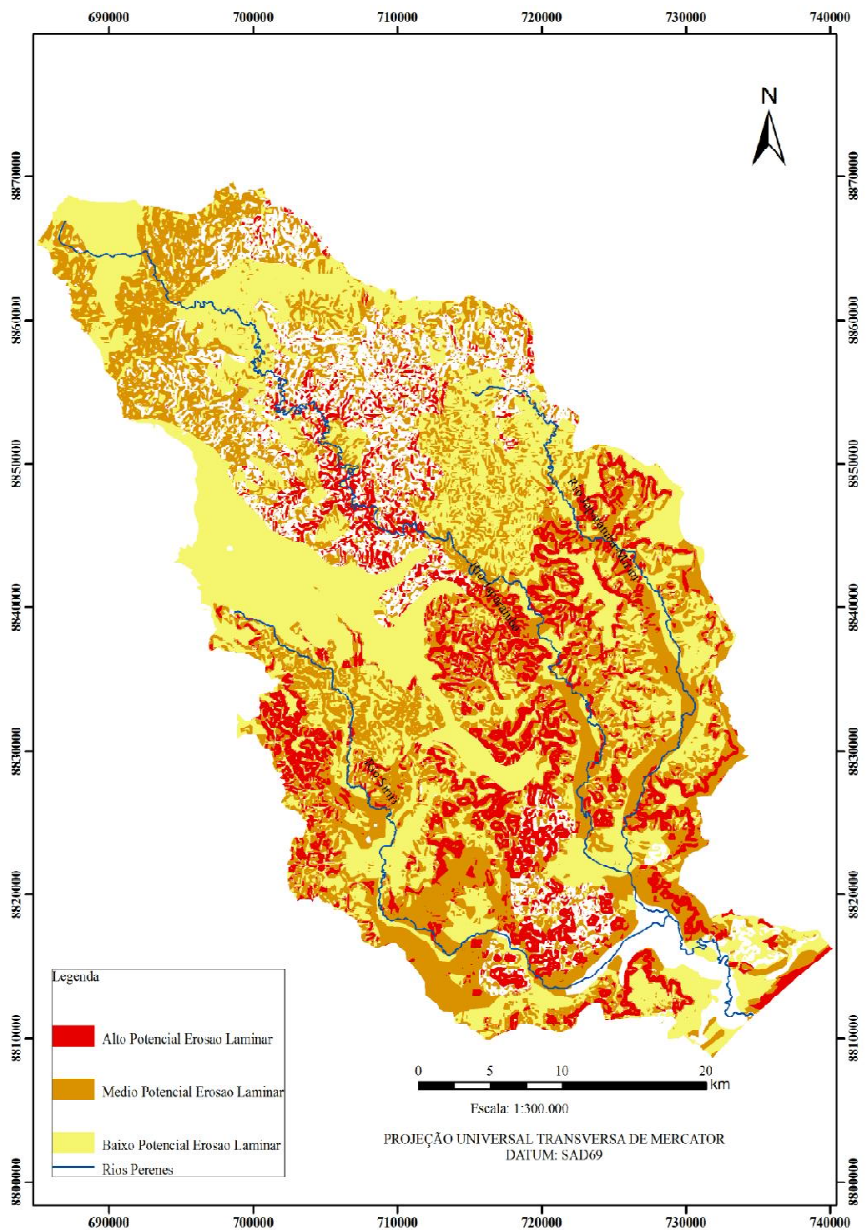

Figura 12. Mapa de potencial a erosão laminar para a Bacia do Rio Japaratuba, SE

a erosão laminar (Classe II), que cobre parcial ou completamente todos os municípios, os solos são do tipo podzólico vermelhoamarelo, solos aluviais e vertissolos, considerados de muito baixa a baixa resistência à erosão. Ressalta-se que, se por um lado as pastagens protegem o solo ao longo do ano, a cultura da cana promove sua movimentação, deixando-o exposto ao processo erosivo. A classe de muito baixo potencial à erosão laminar compreende $11,70 \%$ da área da bacia, que estão sobre solos do tipo podzol e são ocupadas por mangue, áreas embrejadas ou áreas cultivadas. Nesta região a declividade varia de 0 a $2 \%$ e praticamente se encontram nas margens dos rios principais.

Por fim, 39,59\% $\left(667,12 \mathrm{~km}^{2}\right)$ da área da bacia estão na classe de baixo potencial à erosão laminar (classe III de suscetibilidade), cujos principais usos são de mata secundária, florestas, pastagem e área cultivada (cana-de-açúcar). São áreas pouco a não suscetíveis ao processo erosivo, a declividade está entre 0 e 5\%; portanto, segundo a classificação descrita por Salomão (1999), o uso atual do solo é compatível com a suscetibilidade à erosão laminar (Figuras 10, 11, 12), ou seja, não favorece este processo. Nota-se, nesta situação, a presença benéfica da vegetação nativa e da mata secundária contra os efeitos erosivos da chuva.

Com base no exposto, é notável que as áreas de médio e alto potencial à erosão laminar (municípios de Capela, Siriri, Carmópolis, Rosário do Catete, Japaratuba, General Maynard,
Muribeca) são aquelas em que os impactos antrópicos, como desmatamento e extração mineral, ocorrem de forma mais significativa. Esta prática, associada ao tipo de solo e à declividade da região, tem resultado na situação atual. Nas áreas cultivadas ou mesmo naquelas com pasto novo/seco, o risco a erosão é considerável, visto que a combinação de solos de textura arenosa, pasto ou cana-de-açúcar em seu estágio inicial de crescimento, leva a uma pequena cobertura, deixando o solo propício a ser erodido pelo impacto das gotas de chuva.

Os resultados são alarmantes, haja vista que esta região tem sido bastante exigida do ponto de vista dos recursos naturais ao longo dos últimos três séculos e, provavelmente, as devidas técnicas de conservação não tem sido aplicadas a contento, fato que poderá ser observado através da coloração das águas, que evidencia altas cargas de sedimentos; logo, um plano de conservação do solo se faz necessário, a fim de permitir o uso das terras, adequando-o à preservação dos recursos naturais solo e água. Os mapas aqui desenvolvidos refletem as condições relativas à época em que os dados de uso e ocupação do solo foram determinados e deverão ser atualizados periodicamente visando refletir os riscos reais dos processos erosivos.

\section{CONCLUSÕES}

1. Aproximadamente $60 \%$ da área da bacia do Rio Japaratuba estão entre as classes extremamente suscetível e muito suscetível à erosão laminar.

2. As áreas dos municípios de Capela, Siriri, Carmópolis, Rosário do Catete, Japaratuba, General Maynard e Muribeca, são as mais suscetíveis à erosão laminar.

3. Da área total, 48,71\% da área da bacia incluem as classes de médio e alto potencial a erosão laminar e as cidades acima citadas, em virtude do manejo do solo.

4. A combinação formada por solos podzólicos vermelhos, declividades entre 10 e $25 \%$ e solo nu ou área cultivada, é propícia para um alto potencial à erosão laminar.

5. A bacia do Rio Japaratuba está muito impactada e sofre com os usos inadequados para as condições de solo e declividades.

\section{AgRAdECIMENTOS}

Ao Conselho Nacional de Desenvolvimento Científico e Tecnológico - CNPq, através do Projeto "Avaliação dos impactos das ações antrópicas sobre os recursos hídricos numa bacia do Estado de Sergipe", Ed. Universal 02/2006, Proc. n. ${ }^{\circ}$ 477467/2006-7; à Universidade Federal de Sergipe e à Universidade Federal de Campina Grande.

\section{LITERATURA CITADA}

Albuquerque, A. W.; Moura Filho, G.; Santos, J. R.; Costa, J. P. V.; Souza, J. L. Determinação de fatores da equação universal de perda de solo em Sumé, PB. Revista Brasileira de Engenharia Agrícola e Ambiental, v.9, p.153-160, 2005. 
ANA - Agência Nacional de Águas. Hidro - Sistema de Informações Hidrológicas - Versão 1.0 - Manual do Usuário. 2002. 30p.

Aragão, R.; Almeida, J. A. P. Avaliação espaço-temporal do uso do solo na área da bacia do rio Japaratuba - Sergipe através de imagens LANDSAT. In: Simpósio Brasileiro de Sensoriamento Remoto, 14, 2009, Natal. Anais...Natal: INPE, 2009. CD Rom.

Auerswald, K.; Fiener, P.; Dikau, R. Rates of sheet and rill erosion in Germany - A meta-analysis. Geomorphology. v.111, p.182-193, 2009.

Barbosa, Í. S.; Andrade, L. A. de; Almeida, J. A. P. Zoneamento agroecológico do município de Lagoa Seca, PB. Revista Brasileira de Engenharia Agrícola e Ambiental. v.13, p.623632, 2009a.

Barbosa, Í. S.; Andrade, L. A.; Almeida, J. A. P. Evolução da cobertura vegetal e uso agrícola do solo no município de Lagoa Seca, PB. Revista Brasileira de Engenharia Agrícola e Ambiental. v.13, p.614-622, 2009b.

Bazzano, M. G. P.; Eltz, F. L. F; Cassol, E. A. Erosividade e características hidrológicas das chuvas de Rio Grande (RS). Revista Brasileira de Ciência do Solo, v.34, p.235244, 2010.

Bertoni, J.; Lombardi Neto, F. Conservação do solo. 4.ed., São Paulo: Ícone, 355p. 2005.

Câmara, G.; Souza, R. C. M.; Freitas, U. M.; Garrido, J. SPRING: Integrating remote sensing and GIS by object-oriented data modeling. Computers \& Graphics, v.20, p.395-403, 1996.

Crepani, E.; Medeiros, J. S.; Palmeira, A. F.; Silva, E. F.; Zoneamento ecológico-econômico. In: Florenzano, T. G. (org.). Geomorfologia: Conceitos e tecnologias atuais. São Paulo: Oficina de textos, 2008. cap. 10, p.285-316.

Descroix, L.; Brrios, J. L. G.; Viramontes, D.; Poulenard, J.; Anaya, E.; Esteves, M.; Estrada, J. Gully and sheet erosion on subtropical mountains slopes: Their respective roles and the scale effect. Catena, v.72, p.325-339, 2008.

Gonçalves, F. A.; Silva, D. D.; Pruski, F. F. ; Carvalho, D. F.; Cruz, E. S. Índices e espacialização da erosividade das chuvas para o Estado do Rio de Janeiro. Revista Brasileira de Engenharia Agrícola e Ambiental, v.10, p.269-276, 2006.

Guimarães, L. J. R.; Santos, L. J. C. L. Levantamento das áreas potenciais à erosão laminar como suporte à detecção das áreas-fonte ao assoreamento na barragem Piraquara1. Revista Eletrônica Geografar. v.2, p.172-188, 2007.

Inácio, E. S. B.; Cantalice, J. R. B.; Nacif, P. G. S.; Araújo, Q. R.; Barreto, A. C. Quantificação da erosão em pastagem com diferentes declives na Microbacia do Ribeirão Salomea. Revista Brasileira de Engenharia Agrícola e Ambiental, v.11, p.355-360, 2007.
Lorandi, R.; Takemoto, F.; Salvador, N. N. B; Torresan, F. E. Carta de potencial à erosão laminar da parte superior da bacia do córrego do Monjolinho (São Carlos, SP). Revista Brasileira de Cartografia, v.53, p.111-117, 2001.

Lufafaa, A.; Tenywaa, M. M.; Isabiryeb, M.; Majaliwaa, M.J.G.; Woomerc, P.L. Prediction of soil erosion in a Lake Victoria basin catchment using a GIS-based UniversalSoil Loss model. Agricultural Systems, v.76, p.883-894, 2003.

Martins, S. G.; Avanzi, J. C.; Silva, M. L. N.; Curi, N.; Norton, L. D.; Fonseca, S. Rainfall erosivity and rainfall return period in the experimental watershed of Aracruz, in the Coastal plain of Espirito Santo, Brazil. Revista Brasileira de Ciências do Solo, v.34, p.999-1004, 2010.

Merritt, W. S.; Letcher, R. A.; Jakeman, A. J. A review of erosion and sediment transport models. Environmental Modelling \& Software. v.18, p.761-799, 2003.

Nunes, A. N.; Almeida, A. C.; Coelho, C. O. A. Impacts of land use and cover type on runoff and soil erosion in a marginal area of Portugal. Applied Geography, v.31.p. 687-699, 2011.

Pedro, F. G.; Lorandi, R. Potencial natural de erosão na área periurbana de São Carlos-SP. Revista Brasileira de Cartografia v.56, p.28-33, 2004.

Petan, S.; Rusjan, S.; Vidmar; A., Mikoš, M. The rainfall kinetic energy-intensity relationship for rainfall erosivity estimation in the mediterranean part of Slovenia. Journal of Hydrology. v.391, p.314-321, 2010.

Rabus, B.; Eineder, M.; Roth, A.; Bamler, R. The shuttle radar topography-a new class of digital elevation models acquired by space borne radar - ISPRS. Journal of Photogrammetry and Remote Sensing, v.57, p.241-262, 2003.

Ribeiro, F. L.; Campos, S. Vulnerabilidade à erosão do solo da Região do Alto Rio Pardo, Pardinho, SP. Revista Brasileira de Engenharia Agrícola e Ambiental. v.11, p.628-636, 2007.

Ribeiro, L. S.; Alves, M. G. Análise de suscetibilidade à erosão laminar no município de Campos dos Goytacazes-RJ através de técnicas de geoprocessamento. Estudos Geográficos, v.6, p.89-100, 2008.

Salomão, F. X. T. Controle e prevenção dos processos erosivos. In: Guerra, A. J. T; Silva, A. S.; Botelho R. G. M. (org.). Erosão e conservação dos solos. Rio de Janeiro: Bertrand Brasil, 1999, cap. 7. p.229-267.

Santos, G. S.; Nori, P. G. Oliveira, L. F. C. Chuvas intensas relacionadas à erosão hídrica. Revista Brasileira de Engenharia Agrícola e Ambiental, v.14, p.115-123, 2010.

SEPLANTEC - Secretaria de Estado do Planejamento e da Ciência e Tecnologia. Atlas digital de recursos hídricos do Estado de Sergipe. Aracaju, 2004. CD Rom.

Shih, H. M; Yang, C. T. Estimating overland flow erosion capacity using unit stream power. International Journal of Sediment Research. v.24, p.46-62, 2009. 